\title{
Using Ultrasound-Treated Washout from Conifer Needles and Fresh Snow Samples in Air Pollution Monitoring
}

\author{
A. Kholodov $\mathbb{D}^{1}{ }^{1}$ M. Tretyakova, ${ }^{2}$ and $K$. Golokhvast $\mathbb{D}^{2,3,4}$ \\ ${ }^{1}$ Far East Geological Institute, Far East Branch of Russian Academy of Sciences, Vladivostok, Russia \\ ${ }^{2}$ Far Eastern Federal University, Vladivostok, Russia \\ ${ }^{3}$ N.I. Vavilov All-Russian Institute of Plant Genetic Resources, Saint-Petersburgh, Russia \\ ${ }^{4}$ Pacific Geographical Institute, Far Eastern Branch of Russian Academy of Sciences, Vladivostok, Russia \\ Correspondence should be addressed to K. Golokhvast; droopy@mail.ru
}

Received 28 March 2020; Accepted 26 May 2020; Published 23 June 2020

Academic Editor: Ghadir. A. El-Chaghaby

Copyright $\odot 2020$ A. Kholodov et al. This is an open access article distributed under the Creative Commons Attribution License, which permits unrestricted use, distribution, and reproduction in any medium, provided the original work is properly cited.

\begin{abstract}
Snow precipitation and snowpack are commonly used to assess the condition of the aerial environment. Another way to monitor air quality is to study trees and shrubs, which are natural barriers for capturing air pollution, including atmospheric particulate matter. The hypothesis of the current study was that using fresh snow precipitation and washout from vegetation for the monitoring of air pollution can produce comparable results. In this study, we compared the results of laser diffraction analysis of suspended particular matter in melted fresh snow and ultrasound-treated washout from conifer needles. The samples were collected at several sites in Primorsky Krai, Russian Federation, and analyzed according to the same scheme. We observed that the content of particulate matter with a smaller aerodynamic diameter in the ultrasound-treated washout from conifer needles was higher than that in the melted fresh snow. The content of $\mathrm{PM}_{10}$ in the ultrasound-treated washout from conifers was increased by 6-27\% depending on the site, showing greater efficacy of this method. This method can be used as an alternative to the sampling of snow for the monitoring of ambient air pollution, taking into account several limitations.
\end{abstract}

\section{Introduction}

Snow precipitation and snowpack are commonly used to assess the condition of the aerial environment in urban areas and at remote sites $[1,2]$. Falling snow scavenges air pollutants of both anthropogenic and natural origins $[3,4]$. Due to their larger surface area and slower deposition speed, snowflakes absorb more air pollutants compared to raindrops [5]. Urban snowpack is further polluted by the products of combustion, motor vehicle emissions, winter road maintenance chemicals, debris, and litter, turning it into a "toxic cocktail of pollutants" [6, 7]. For certain types of analysis, e.g., for particle size distribution analysis of melted fresh snow, the sample preparation is minimal. Also, snow samples are inexpensive and easy to collect and handle.

However, snow sampling has its limitations. The main limitation is seasonality, meaning that scientists need to switch to other sampling methods during the snowless period. The time of sampling is also important. Snowpack samples must be collected before melting, and rain-on-snow events can destroy the samples [8]. Fresh snow should be collected during or immediately after the snowfall.

Another way to monitor air quality is to study the vegetation. Trees and shrubs are natural barriers for capturing air pollution, including atmospheric particulate matter (PM) [9]. Due to their leaf structure and other properties, conifers are more effective in accumulating fine and coarse particles (aerodynamic diameter $(D p)>1 \mu \mathrm{m}$ ), while broad-leaved species accumulate more ultrafine particles $(\mathrm{Dp}<1 \mu \mathrm{m})[10] . \mathrm{PM}_{10}$ particles are a complex heterogeneous mixture of solids and liquid droplets floating in the air in the size range of $2.5-10 \mu \mathrm{m}$ in diameter and, depending on the composition, they may pose a threat to human health [11].

A comprehensive study by Nowak et al. [9] reported that urban trees remove about 215 thousand tons of $\mathrm{PM}_{10}$ in the 
US per year. A study at two sites in Europe (Norway and Poland) ranked 47 woody species by their ability to accumulate roadside PM, and it was found that Pinus sylvestris was among the species most efficient in capturing PM [12]. Another experimental study in Beijing Botanical Garden showed that two pine species, Pinus tabuliformis and Pinus bungean, captured more total suspended particles per unit leaf area compared to broad-leaved tree species [13].

The goal of this study was to verify if using fresh snow and vegetation for environmental monitoring could produce comparable results. For this purpose, we compared the results of particle size distribution analysis of suspended particular matter in melted fresh snow and ultrasoundtreated washout from conifer needles. The samples were collected at several sites and analyzed according to the same scheme.

\section{Experiments}

In this study, we compared the results of the particle size analysis of melted snow and ultrasound-treated washout from conifer needle samples collected at several sites in Primorsky Krai, Russian Federation. Conifer species used for this study were Khingan fir (Abies nephrolepis), Manchurian fir (Abies holophylla), Korean pine (Pinus koraiensis), and Scots pine (Pinus sylvestris).

The first site $\left(n_{1}=3, n_{2}=3\right.$, where $n_{1}$ is the number of snow samples at the site and $n_{2}$ is the number of conifer needle samples at the site) is a small urban settlement Terney $\left(45^{\circ} 02^{\prime} \mathrm{N}, 136^{\circ} 36^{\prime} \mathrm{E}\right.$; area of $3.5 \mathrm{~km}^{2},>3000$ inhabitants) located in an environmentally favorable area near the Sikhote-Alin nature reserve. The samples were collected in the winter of 2017. The data used in this study are modified from previous research by Kodintsev et al. [14].

The second site $\left(n_{1}=8, n_{2}=10\right)$ is the Spassk-Dalny town $\left(44^{\circ} 36^{\prime} \mathrm{N}, 132^{\circ} 49^{\prime} \mathrm{E}\right.$; area of $43.5 \mathrm{~km}^{2},>40,000$ inhabitants). The cement plant located in the town is a recognized source of environmental pollution. The snow samples were collected in the winter of 2017-2018, and the confer needle samples were collected in the summer of 2018.

The third site $\left(n_{1}=8, n_{2}=10\right)$ is the Nakhodka city $\left(42^{\circ} 49^{\prime} \mathrm{N}, 132^{\circ} 52^{\prime} \mathrm{E}\right.$; area of $325.9 \mathrm{~km}^{2},>147,000$ inhabitants), mainly its port complex, which is the second largest port in Russia in terms of cargo turnover. The port complex currently deals with the transshipment of coal. The samples were collected in January of 2020.

Snow samples were collected from $1 \mathrm{~m}^{2}$ area into 3-liter plastic containers prewashed with distilled water. To avoid the secondary pollution of settled snow, only the top layer of fresh snow was collected. After collection, the snow samples were transported to the laboratory of Research and Educational Center Nanotechnology (FEFU), where the melted snow was analyzed for particle size distribution.

Conifer needles were collected according to the previously described method $[14,15]$ from trees at the height of
$1-1.5 \mathrm{~m}$ and carefully transported to the lab. In the laboratory, the containers with sample needles were filled with double-distilled water and cleaned with ultrasound using a Sonopulse 3100 HD ultrasonic homogenizer (Bandelin electronic GmbH \& Co. KG, Germany) at $22 \mathrm{kHz}, 100$ watts, and a 5-minute exposure to remove the pollution particles from the needles. The settings were determined after a series of experiments, where the surface of needles was examined using a microscope after ultrasound cleaning at various settings to verify that most of the fine dust particles were cleaned from the surface into the solution. No additional preparation of conifer needle samples was made.

Both the melted snow samples and the ultrasoundtreated washout from conifer needle samples were analyzed for particle size distribution using the Analysette 22 NanoTec plus laser particle sizer (Fritsch GmbH, Germany). The measurements were run at the settings of quartz/water at $20^{\circ} \mathrm{C}$ in three repeats. The results were analyzed with Fritch MaS software using the Mie-Gruneisen equation of state. Statistical analyses were performed in the software package STATISTICA 10 (StatSoft, Inc., USA).

\section{Results}

The suspended particles were classified into seven groups depending on their aerodynamic diameter: (1) $0.1-1 \mu \mathrm{m}$ $\left(\mathrm{PM}_{1}\right)$, (2) 1-10 $\mu \mathrm{m}\left(\mathrm{PM}_{10}\right)$, (3) $10-50 \mu \mathrm{m}$, (4) $50-100 \mu \mathrm{m}$, (5) $100-400 \mu \mathrm{m}$, (6) $400-700 \mu \mathrm{m}$, and (7) $\geq 700 \mu \mathrm{m}$ [16]. This classification was used in the interpretation of the laser particle size analysis results.

The particle size distribution patterns in the samples from the first site (Terney settlement, fresh snow, and conifer needles) are closely comparable (Figure 1). The median of the content of $\mathrm{PM}_{10}$ in the washout from conifer needle samples is higher by $>15 \%$. It should be mentioned here that the number of samples collected at this pilot site did not allow us to present significant graphs of statistical data, unlike other sites used in this study (Figures 2 and 3).

The second site (Spassk-Dalny) is an industrial town with a cement plant. The industrial impact on the atmosphere manifests in the increased content of smaller fractions of particulates in the washout from conifer needle samples. In the melted snow, the suspended particles are distributed more evenly $\left(\mathrm{PM}_{10}\right.$ median is $\left.20.9 \%\right)$, while in the conifer needles, there is an increase in the content of both $\mathrm{PM}_{1}$ and $\mathrm{PM}_{10}\left(\mathrm{PM}_{10}\right.$ median is $\left.47.3 \%\right)$ (Figures 2 and 4 ).

The samples from Nakhodka city demonstrate the same trend: the average content of finer fractions is higher in conifer needle samples. The content of $\mathrm{PM}_{1}$ is almost twice high $(2.3 \%$ and $4.2 \%)$, and $\mathrm{PM}_{10}$ content is increased by $5.3 \%$ $\left(\mathrm{PM}_{10}\right.$ median in snow samples is $32.8 \%$, in conifer needles $38.1 \%)$. The $\mathrm{PM}_{10}$ values are relatively high and reflect the industrial nature of the particulate matter in the sampling area (Figures 3 and 5).

The increased content of smaller fractions in an ultrasound-treated washout from conifer needle samples observed in the study may be caused by the fact that due to their surface properties, conifer needles capture more PM. Another reason may be that the ultrasound treatment breaks 


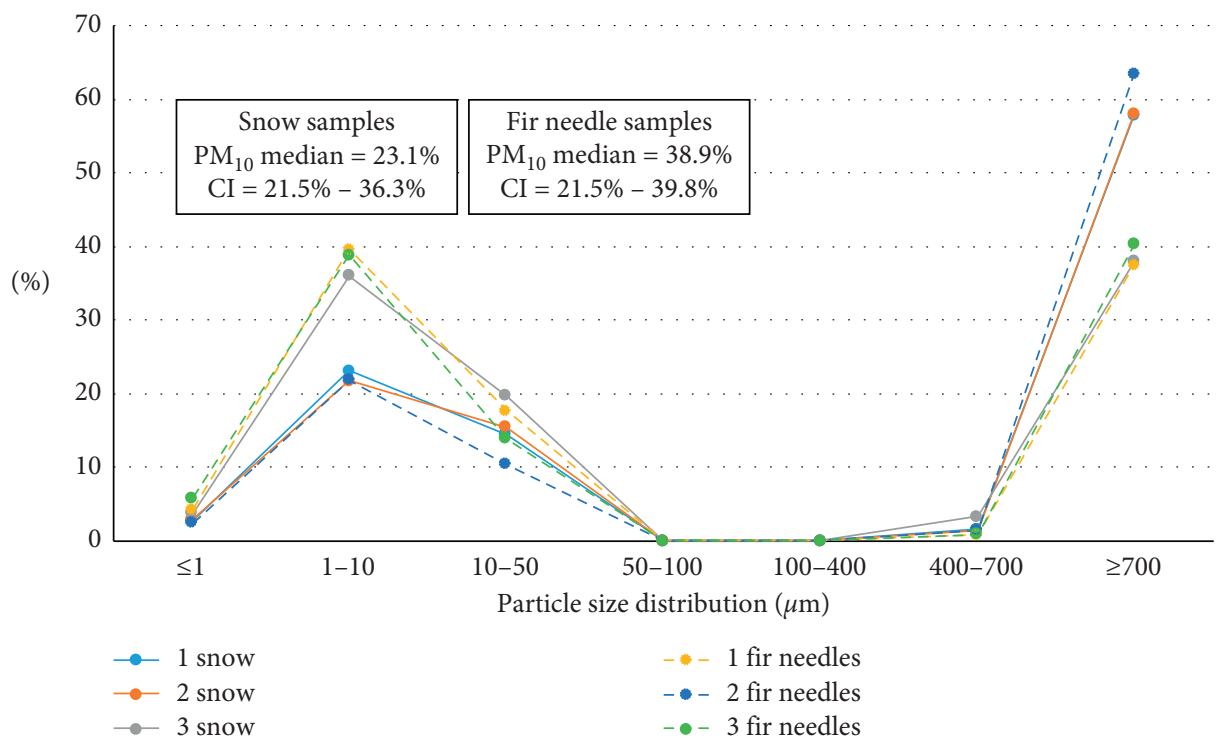

Figure 1: Particle size distribution of particulate matter measured in melted snow samples and in ultrasound-treated washout from conifer needle samples from Terney town. The figure is based on the data from [14].

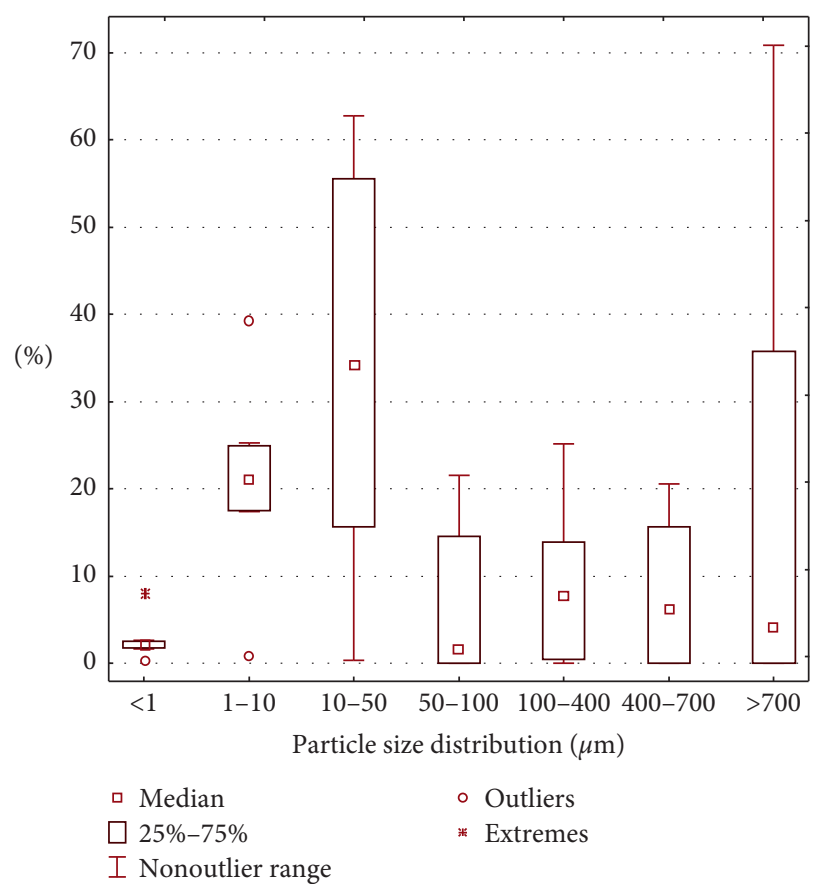

(a)

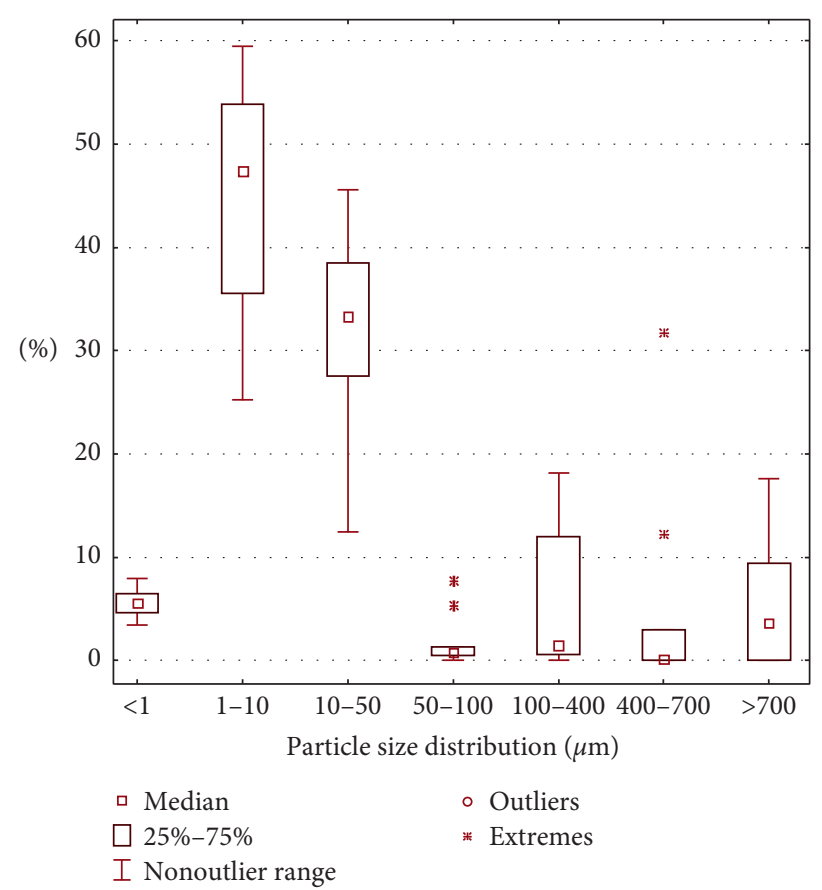

(b)

Figure 2: Statistical data of PM particle size distribution in Spassk-Dalny town (a) in melted snow samples and (b) in ultrasound-treated washout from conifer needle samples.

particle aggregates into PM of smaller aerodynamic diameter.

\section{Discussion}

In the study, we collected freshly fallen snow to assess the pollutants that were in the air, without the burden of secondary pollution in the snow cover. The range and the extent of pollutants in snow cover are known to be higher than that in the precipitation [17]. Even more so, the pollutants may react with snow, and resulting admixtures are released into melt water and soil during winter even in cold climate due to temperature fluctuations and thaws [6]. Due to this, even snowpack does not accurately represent the accumulated pollution.

Our study showed a higher content of PM fractions with a smaller aerodynamic diameter in the washout from conifer needles compared to the fresh snow. This trend was observed 


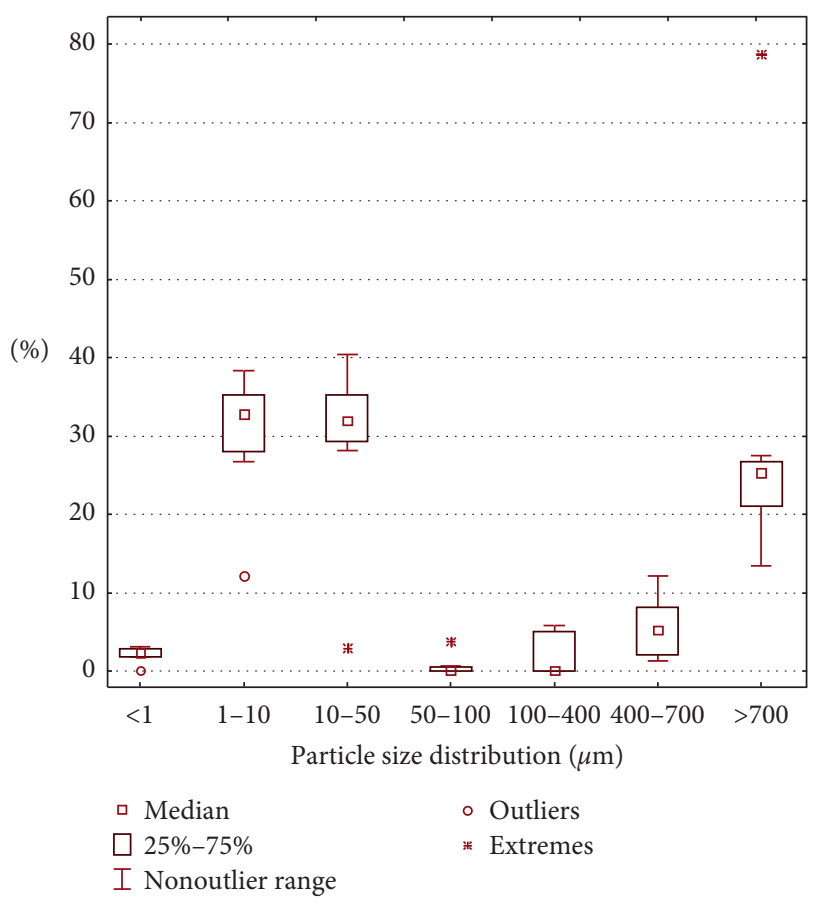

(a)

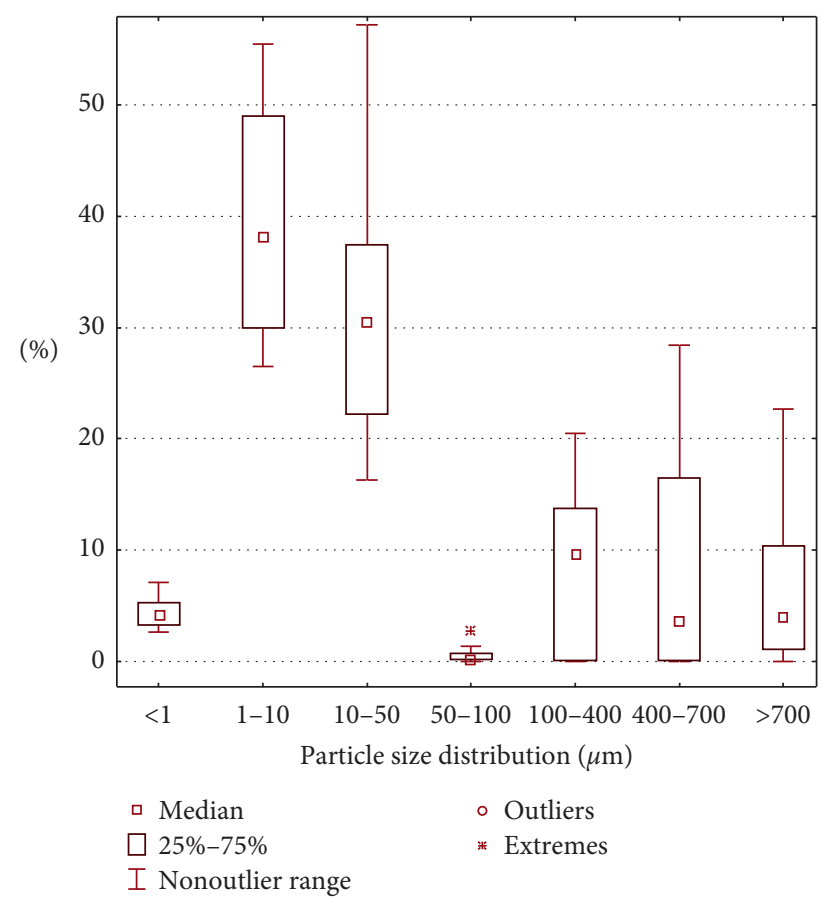

(b)

FIgURE 3: Statistical data of PM particle size distribution in Nakhodka city; (a) in melted snow samples and (b) in ultrasound-treated washout from conifer needle samples.

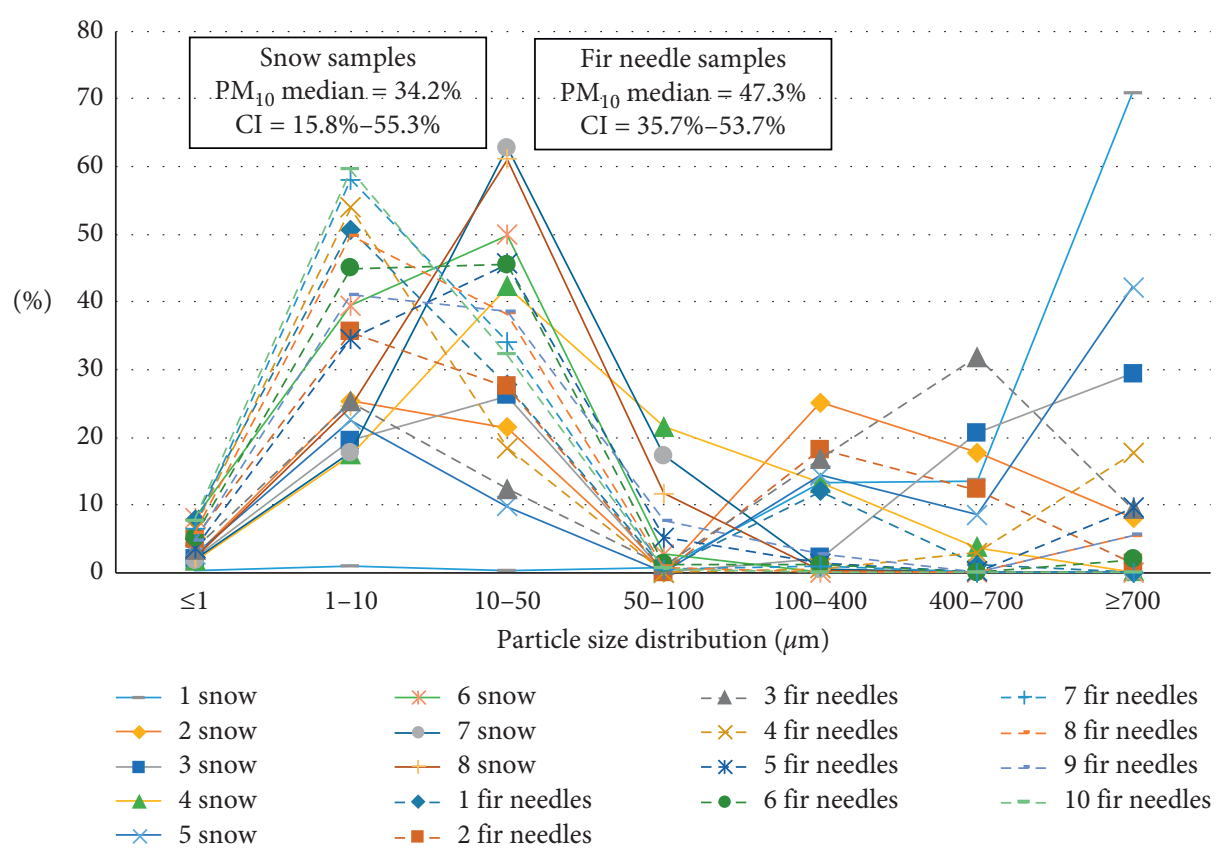

Figure 4: Particle size distribution of particulate matter measured in melted snow samples and in ultrasound-treated washout from conifer needle samples from Spassk-Dalny town.

in all three sites: $15.8 \%$ increase in site 1 (Terney town), $13.1 \%$ in site 2 (Spassk-Dalny town), and over $5.3 \%$ in site 3 (Nakhodka city). One of the reasons for this trend is that conifer tree species are effective in capturing fine atmospheric PM on their surface $[9,11,13]$.
Another reason for the elevated content of smaller PM in conifer needles may be the use of an ultrasound cleaning technique. Washing the sticky leaf-needles efficiently to get the pollutants into the solution was a challenge in the study. Hand washing and shaking of sample material still left 


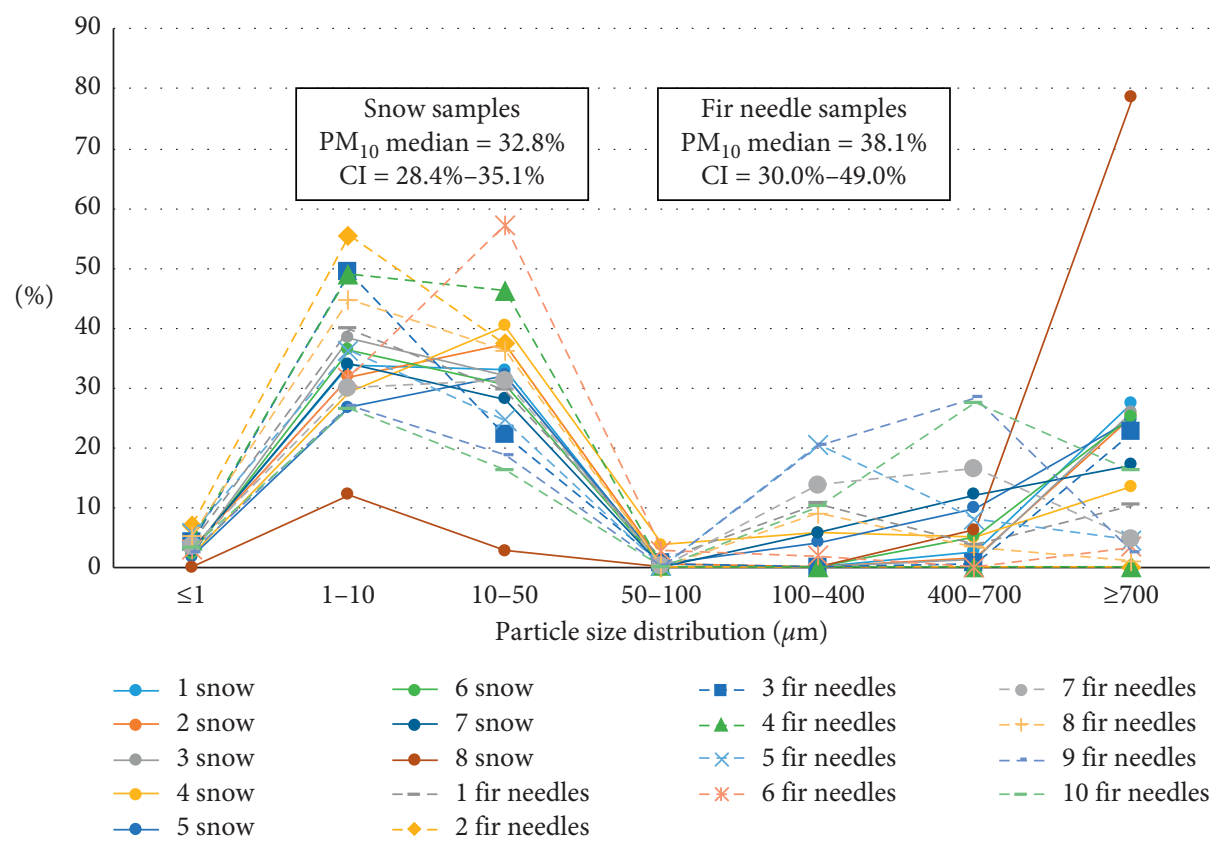

Figure 5: Particle size distribution of particulate matter measured in melted snow samples and in ultrasound-treated washout from conifer needle samples from Nakhodka city.

pollutant particles on the surface of samples [18]. A known way to clean the surface of plant samples is ultrasonic treatment. In 1979, Godzik et al. [19] used chloroform and ultrasonic cleaning technique to remove particulates from the leaves of oak and pine. The method was modified (chloroform was substituted with water) and further used to remove pollutants from various types of plants, vegetation, and fresh produce [20-22]. Both ultrasonic probes and baths are used with low frequencies ranging from 20 to $40 \mathrm{kHz}$. Experimentally, we found that the parameters of $22 \mathrm{kHz}, 100$ watts, and a 5-minute exposure removed most particles from leaves and needles. The increase of $\mathrm{PM}_{10}$ particles in the solution was by $10.4 \%-26.6 \%$ compared to simply rinsing the conifer needles in the water [23]. While this is an effective method to get particulates into the solution, it has its limitations, as it was reported that ultrasonic treatment may cause a decrease in particle size and narrow the distribution of particulates [24].

In earlier studies of the authors of this article/paper, the dried sediment from melted snow and ultrasound-treated washout from conifer needles was effectively used for further analysis of the environment. The morphology of particles, the content of heavy metals, and Raman spectra of particles were analyzed, allowing them to identify metals, cement, and coal in ambient PM $[15,25,26]$.

A sampling of snow and conifer needles makes it possible to conduct inexpensive environmental monitoring regardless of the season and get comparable results. However, certain limitations of both methods should be taken into consideration. In territories with colder climate, anthropogenic emissions of potentially toxic substances from coal combustion are much higher in the heating season than during the nonheating season. While coniferous species are efficient in the removal of particulate matter from ambient air during the heating season [27], they are exposed to contamination for long time periods and that may affect the monitoring results. In the snowless season, rainstorms should be taken into account, which can naturally wash the surface of leaves and clean them from pollutants $[28,29]$.

\section{Conclusions}

In the study, we compared the results of laser diffraction analysis of melted fresh snow samples and ultrasound-treated washout from conifer needle samples taken at three sites. Our results showed greater efficacy of ultrasound washout from conifer needles in the study of suspended particles, as this method allows a greater number of smaller particles to be deposited into the solution. This method can be used as an all-season alternative to the sampling of snow for the monitoring of ambient air pollution. Certain limitations of both methods should be considered.

The assessment of air quality is an important part of environmental monitoring. The sampling and analysis methods described in this study are relatively easy and costeffective ways of monitoring, especially in conditions of remote areas and smaller settlements.

\section{Data Availability}

The data used to support the findings of this study are available from the corresponding author upon request.

\section{Conflicts of Interest}

The authors declare no conflicts of interest.

\section{Acknowledgments}

This research was funded by the Russian Fund for Basic Research, grant number 19-05-50010. 


\section{References}

[1] P. Siudek, M. Frankowski, and J. Siepak, "Trace element distribution in the snow cover from an urban area in central Poland," Environmental Monitoring and Assessment, vol. 187, no. 5, p. 225, 2015.

[2] A. P. Nawrot, K. Migała, B. Luks, P. Pakszys, and P. Głowacki, "Chemistry of snow cover and acidic snowfall during a season with a high level of air pollution on the Hans Glacier, Spitsbergen," Polar Science, vol. 10, no. 3, pp. 249-261, 2016.

[3] Y. Liu, B. Fu, C. Liu et al., "Scavenging of atmospheric particulates by snow in Changji, China," Global NEST Journal, vol. 20, no. 3, pp. 471-476, 2018.

[4] V. P. Shevchenko, A. P. Lisitsyn, A. A. Vinogradova et al., "Dispersed sedimentary matter of the atmosphere," in Biogeochemistry of the Atmosphere, Ice and Water of the White Sea, A. Lisitsyn and V. Gordeev, Eds., Springer, Berlin, Germany, pp. 9-46, 2018.

[5] F. Cereceda-Balic, M. R. Palomo-Marín, E. Bernalte et al., "Impact of Santiago de Chile urban atmospheric pollution on anthropogenic trace elements enrichment in snow precipitation at Cerro Colorado, Central Andes," Atmospheric Environment, vol. 47, pp. 51-57, 2012.

[6] Y. Nazarenko, S. Fournier, U. Kurien et al., "Role of snow in the fate of gaseous and particulate exhaust pollutants from gasoline-powered vehicles," Environmental Pollution, vol. 223, pp. 665-675, 2017.

[7] A. Vijayan, H. Österlund, J. Marsalek, and M. Viklander, "Laboratory melting of late-winter urban snow samples: the magnitude and dynamics of releases of heavy metals and PAHs," Water, Air, \& Soil Pollution, vol. 230, no. 8, p. 182, 2019.

[8] K. Jenkins, A. Woodward, and E. Schreiner, "A framework for long-term ecological monitoring in olympic national park: prototype for the coniferous forest biome," in U.S. Geological Survey, Biological Resources Discipline, Information and Technology Report, p. 150, U.S. Geological Survey, Reston, VA, USA, 2003.

[9] D. J. Nowak, D. E. Crane, and J. C. Stevens, "Air pollution removal by urban trees and shrubs in the United States," Urban Forestry \& Urban Greening, vol. 4, no. 3-4, pp. 115-123, 2006.

[10] P. H. Freer-Smith, K. P. Beckett, and G. Taylor, "Deposition velocities to Sorbus aria, Acer campestre, Populus deltoides $\times$ trichocarpa "Beaupré", Pinus nigra and $\times$ Cupressocyparis leylandii for coarse, fine and ultra-fine particles in the urban environment," Environmental Pollution, vol. 133, no. 1, pp. 157-167, 2005.

[11] WHO Regional Office for Europe, Health Risk Assessment of Air PollutionGeneral Principles, WHO Regional Office for Europe, Copenhagen, Denmark, 2016.

[12] A. Sæbø, R. Popek, B. Nawrot et al., "Plant species differences in particulate matter accumulation on leaf surfaces," Science of The Total Environment, vol. 427-428, pp. 347-354, 2012.

[13] W. Zhang, B. Wang, and X. Niu, "Relationship between leaf surface characteristics and particle capturing capacities of different tree species in Beijing," Forests, vol. 8, no. 3, p. 92, 2017.

[14] V. V. Kodintsev, V. A. Drozd, I. V. Seryodkin et al., "Ultrasound flushes from the needles as a new method of investigation of air microdimensional pollution," Bulletin Physiology and Pathology of Respiration, vol. 1, no. 65, pp. 90-93, 2017, in Russian.

[15] A. Kholodov, A. Zakharenko, V. Drozd et al., "Identification of cement in atmospheric particulate matter using the hybrid method of laser diffraction analysis and Raman spectroscopy," Heliyon, vol. 6, no. 2, Article ID e03299, 2020.

[16] K. S. Golokhvast, I. Yu. Chekryzhov, I. L. Revutskaya et al., "Some aspects of atmospheric suspenses modeling based on material composition," Izvestia of Samara Scientific Center of the Russian Academy of Sciences, vol. 14, no. 1-9, pp. 24012404, 2012, in Russian.

[17] I. I. Kondrat'ev, D. E. Mukha, A. G. Boldeskul, S. G. Yurchenko, and T. N. Lutsenko, "Chemical composition of precipitation and snow cover in the Primorsky krai," Russian Meteorology and Hydrology, vol. 42, no. 1, pp. 64-70, 2017.

[18] N. A. Borodina, "Accumulation of heavy metals by pine needles in urban ecosystem of Blagoveshchensk city," Izvestia of Samara Scientific Center of the Russian Academy of Sciences, vol. 1, no. 8, pp. 1958-1962, 2012, in Russian.

[19] S. Godzik, T. Florkowski, S. Piorek, and M. M. A. Sassen, “An attempt to determine the tissue contamination of Quercus robur L. and Pinus silvestris L. foliage by particulates from zinc and lead smelters," Environmental Pollution (1970), vol. 18, no. 2, pp. 97-106, 1979.

[20] M. Cuske, A. Karczewska, and B. Gałka, "Ultrasonic cleaning of plant roots in their preparation for analysis on heavy metals," Zeszyty Naukowe Uniwersytetu Zielonogórskiego, vol. 155, no. 35, pp. 25-32, 2014.

[21] B. Lozowicka, M. Jankowska, I. Hrynko, and P. Kaczynski, "Removal of 16 pesticide residues from strawberries by washing with tap and ozone water, ultrasonic cleaning and boiling," Environmental Monitoring and Assessment, vol. 188, no. 1, p. 51, 2016.

[22] S. Palma, B. Zhou, and H. Feng, "Fresh produce treated by power ultrasound," in Ultrasound: Advances in Food Processing and Preservation, D. Bermudez-Aguirre, Ed., Academic Press, Cambridge, MA, USA, pp. 201-213, 2017.

[23] V. V. Kodintzev, V. V. Chayka, V. E. Kutay et al., "Studying of microdimensional pollution of the atmosphere of the Khingan reserve (Amur region) by means of the method of ultrasonic cleaning of needles," Ecology of Urban Areas, vol. 1, pp. 6-11, 2017, in Russian.

[24] A. R. Jambrak, T. J. Mason, V. Lelas, L. Paniwnyk, and Z. Herceg, "Effect of ultrasound treatment on particle size and molecular weight of whey proteins," Journal of Food Engineering, vol. 121, pp. 15-23, 2014.

[25] K. Golokhvast, T. Vitkina, T. Gvozdenko et al., "Impact of atmospheric microparticles on the development of oxidative stress in healthy city/industrial seaport residents," Oxidative Medicine and Cellular Longevity, vol. 2015, Article ID 412173, 10 pages, 2015.

[26] K. Yu. Kirichenko, A. S. Kholodov, I. A. Vakhniuk et al., "Research of air pollution with fine coal dust (Nakhodka, Primorsky krai)," Bulletin of Kamchatka State Technical University, vol. 50, pp. 6-13, 2019, in Russian.

[27] A. Przybysz, G. Nersisyan, and S. W. Gawroński, "Removal of particulate matter and trace elements from ambient air by urban greenery in the winter season," Environmental Science and Pollution Research, vol. 26, no. 1, pp. 473-482, 2019.

[28] H. Wang, H. Shi, and Y. Wang, "Effects of weather, time, and pollution level on the amount of particulate matter deposited on leaves of Ligustrum lucidum," The Scientific World Journal, vol. 2015, Article ID 935942, 8 pages, 2015.

[29] R. Sett, "Responses in plants exposed to dust pollution," Horticulture International Journal, vol. 1, no. 2, pp. 53-56, 2017. 